\title{
Bone Marrow Cells in Acute Lymphoblastic Leukemia Create a Proinflammatory Microenvironment Influencing Normal Hematopoietic Differentiation Fates
}

\author{
Armando Vilchis-Ordoñez, ${ }^{1,2,3}$ Adriana Contreras-Quiroz, ${ }^{2,4}$ Eduardo Vadillo, ${ }^{2}$ \\ Elisa Dorantes-Acosta, ${ }^{1}$ Alfonso Reyes-López, ${ }^{1}$ Henry Martin Quintela-Nuñez del Prado, ${ }^{5}$ \\ Jorge Venegas-Vázquez, ${ }^{5}$ Hector Mayani, ${ }^{2}$ Vianney Ortiz-Navarrete, ${ }^{4}$ \\ Briceida López-Martínez, ${ }^{1}$ and Rosana Pelayo ${ }^{2}$ \\ 1 "Federico Gómez" Children's Hospital, 06720 Mexico City, DF, Mexico \\ ${ }^{2}$ Oncology Research Unit, Oncology Hospital, Mexican Institute for Social Security, Avenida Cuauhtemoc 330, \\ Colonia Doctores, 06720 Mexico City, DF, Mexico \\ ${ }^{3}$ Clinical Biochemistry Program, National Autonomous University of Mexico, 04510 Mexico City, DF, Mexico \\ ${ }^{4}$ Molecular Biomedicine Department, CINVESTAV, 07360 Mexico City, DF, Mexico \\ ${ }^{5}$ UMAE “Dr. Victorio de la Fuente Narvaéz", Mexican Institute for Social Security, 07760 Mexico City, DF, Mexico
}

Correspondence should be addressed to Rosana Pelayo; rosanapelayo@gmail.com

Received 27 June 2014; Accepted 10 September 2014

Academic Editor: Juan Manuel Mejía-Aranguré

Copyright (C) 2015 Armando Vilchis-Ordoñez et al. This is an open access article distributed under the Creative Commons Attribution License, which permits unrestricted use, distribution, and reproduction in any medium, provided the original work is properly cited.

\begin{abstract}
B-cell acute lymphoblastic leukemia (B-ALL) is a serious public health problem in the pediatric population worldwide, contributing to $85 \%$ of deaths from childhood cancers. Understanding the biology of the disease is crucial for its clinical management and the development of therapeutic strategies. In line with that observed in other malignancies, chronic inflammation may contribute to a tumor microenvironment resulting in the damage of normal processes, concomitant to development and maintenance of neoplastic cells. We report here that hematopoietic cells from bone marrow B-ALL have the ability to produce proinflammatory and growth factors, including TNF $\alpha$, IL-1 $\beta$, IL-12, and GM-CSF that stimulate proliferation and differentiation of normal stem and progenitor cells. Our findings suggest an apparently distinct $\mathrm{CD} 3^{+} \mathrm{CD}_{3} 3^{+}$population of leukemic cells contributing to a proinflammatory microenvironment that may be detrimental to long-term normal hematopoiesis within B-ALL bone marrow.
\end{abstract}

\section{Introduction}

Inflammatory cells and their products are important regulators of the tumor microenvironment. Based on experimental models and epidemiological data, increasing evidence has suggested the close connection between chronic inflammation and carcinogenesis, particularly in colorectal cancer, gastric cancer, and liver and lung neoplastic diseases [1-3]. Moreover, it has been estimated that about $25 \%$ of tumors are associated with chronic inflammatory processes caused by infections or unknown causes [1]. Inflammation may associate with cancer through two potentially connected pathways: the extrinsic, which results from external factors promoting latent inflammatory responses, and the intrinsic, conducted by oncogenes or tumor suppressor genes that activate the expression of inflammation-related programs [4]. For both of them, the cellular and cytochemical components within the tumor microenvironment are crucial. Macrophages are the most widely described inflammatory cells related to cancer $[5,6]$, while tumor-associated fibroblasts have been identified as good producers of proinflammatory cytokines and growth factors in skin, breast, and pancreas malignancies [7]. The participation of cells of the immune response in the initiation, growth, and tumor progression, as well as in the response to antineoplastic therapy, is apparently mediated by a variety of proinflammatory cytokines, including IL-1 $\beta$, 
IL-1 $\alpha$, TNF $\alpha$, IL-6, IL-12, and IFN $\gamma$, and chemokines as CCL2 and CXCL12 $[8,9]$. They play a role in tumorigenesis and tumor-associated inflammation has made them potential targets for adjuvant therapy in cancer. Of special interest, transcription factors such as $\mathrm{NF} \kappa \mathrm{B}$ and STAT3 may cooperate to promote the development and progression of cancer, by controlling the expression of antiapoptotic and proliferative genes, in addition to intervening in the regulation of angiogenesis and invasion $[1,8,10]$. Accordingly, the TLR-MyD88 signaling pathway has been shown to promote tumorigenesis in primary carcinogen models. Thus, together, cytokines, chemokines, and their receptors are keys to the binomial cancer-inflammation entity, compromising sometimes the physiological functions and promoting normal cell senescence, concomitant to proliferation and survival of tumor cells with invasive and metastatic properties $[9,11]$.

Despite the increasing evidence of anomalies in the bone marrow microenvironment of hematologic malignancies, which may govern stem cell activity and lead to disease (reviewed in $[12,13]$ ), knowledge about the role of inflammation in leukemogenesis is scarce. At present, B-cell acute lymphoblastic leukemia is the most common cause of cancer in children worldwide. It is characterized by uncontrolled production of hematopoietic B-precursor cells within bone marrow (BM), with inexorable damage to their differentiation and functional properties. Although a number of genetic aberrations potentially contribute to leukemogenesis, the cellular origin of B-ALL is a fundamental issue under research $[12,14,15]$. Both, cell culture systems and animal models of human-mouse xenotransplantation and leukemic reconstitution suggest that leukemia-initiating cells have characteristics of primitive progenitors [16] and are sensitive to instability lineage triggered by extrinsic stimuli $[13,17]$. According to the original hypothesis of leukemogenesis of Greaves, the occurrence of multiple consecutive lesions in hematopoietic cells can trigger malignant transformation, opening the possibility that not only the oncogenic damage inherent in the early stages of development, but abnormal microenvironmental factors could contribute directly or indirectly to generation or maintenance of leukemic precursors [18]. The implication of specific genetic aberrations in the triggering of ALL-inflammation setting will be highly relevant to investigate. A role of the fusion gene ETV/RUNX1 TEL/AML1 in the TGF signaling constitutes a milestone entailing this immune regulatory pathway to leukemogenesis, by compromising the normal cell responses to its inhibitory function. Accordingly, the favoring of reactive oxygen species by ETV6/RUNX1 has been recently reported that apparently origins in the B-cell progenitor compartment [19-21]. Furthermore, the competition of leukemic cells with normal hematopoietic cells by the normal marrow niches and their apparent contribution to formation of abnormal inhibitory microenvironments have suggested the exhaustion or migration of normal precursors, resulting in almost total BM replacement by malignant cells [22-24]. Remarkably, B-ALL primitive cells before and upon cultures have been shown to produce high levels of TNF $\alpha$ and IL-6, suggesting that an inflammatory microenvironment prevails in this $\mathrm{BM}$ disorder ([25, 26] and our unpublished observations).
More recently, the studies from Guzman et al. indicate that leukemic stem cells in acute myeloid leukemia have constitutively activated the transcription factor $\mathrm{NF} \kappa \mathrm{B}[27,28]$, a fact that may, in turn, harm the normal biology of hematopoietic niches. To determine whether lymphoblastic leukemia precursors contribute to an inflammatory $\mathrm{BM}$ microenvironment that may impact the earliest hematopoietic development from the onset of the disease, we have now investigated and confirmed the production of soluble factors, including cytokines, chemokines, and growth factors by mononuclear cells from B-ALL BM. By using in vitro proliferation assays and controlled culture systems, the impact of ALL-derived proinflammatory factors on normal hematopoietic differentiation potentials was examined, suggesting that within ALL marrow, normal primitive cells are driven into cycle and prompted to produce both lymphoid and innate lineage cells.

\section{Materials and Methods}

2.1. Patient Characteristics and Sample Collection. Fiftyfour children referred to the "Federico Gomez" Children's Hospital (Mexico City, Mexico) and diagnosed with B-cell precursor acute lymphoblastic leukemia were included in the study. Among them, 34 patients fulfilled the criteria for highrisk disease by blood cell count, age, T-cell phenotype, or $\mathrm{Ph}+$ chromosome, whereas 17 for fulfilled the criteria standardrisk. Within the high-risk group, $35 \%$ of the patients were female and $65 \%$ were male, while the standard risk group included $24 \%$ female and $76 \%$ male patients. The median age values were 7.8 year old ( 2 mo-18 yr) and 4.8 ( 2 yr-9 yr) for the high-risk and standard-risk group, respectively. BM specimens were collected by aspiration before any treatment, respecting international and institutional guidelines. Control BM specimens were obtained from healthy children undergoing minor orthopedic surgery. All procedures were approved by the Ethics, Research and Biosafety Committee of the "Federico Gómez" Children's Hospital (Registry HIM/018/2013) in Mexico City. Umbilical cord blood (UCB) samples were obtained from normal full-term neonates. All samples were collected after informed consent from the parents.

2.2. ALL Phenotyping and Pattern Definition. Patients fulfilling morphological criteria of ALL according to the FrenchAmerican-British group (FAB) were stratified in line with clinical risk of relapse and phenotypic expression of CD10, CD19, CD20, CD22, CD79 $\alpha$, Kappa, Lambda, anti TdT, CD3, CD5, CD7, CD13, CD14, CD15, CD33, myeloperoxidase, $\mathrm{CD} 45$, and CD34. Patient groups were further defined in accordance with aberrant expression of myeloid markers, with $25 \%$ of the cells expressing the myeloid antigen being considered as positive. Cytokine production based on the expression of two or more antigens was assessed in ALL.

\subsection{Cell Isolation and Supernatant Collection. Mononuclear} cells (MNC) from B-cell precursor ALL patients were prepared by Ficoll-Paque Plus (GE Healthcare Bioscience) gradient separation and placed in culture with Alpha MEM medium (Gibco by Life Technologies) (200,000 MNC per 
$200 \mu \mathrm{L}$ medium). Supernatants were collected at $24 \mathrm{~h}$ and evaluated for cytokine concentration (experimental time = $24 \mathrm{~h}$ ). Additional $200 \mu \mathrm{L}$ of culture medium was added to the same cells and their supernatants were reevaluated $24 \mathrm{~h}$ later (experimental time $=48 \mathrm{~h})$.

2.4. Cytokine Detection. Supernatants were collected and stored at $-20^{\circ} \mathrm{C}$ until analysis. The cytokine, chemokine, and growth factor content in supernatants were measured by Multiplex Milliplex Map Immunoassay (Merck Millipore), following the manufacturer's recommended protocols. The assay included SDF-1, BCA-1, LIF, TRAIL, SCF, TSLP, FGF-2, Flt-3L, G-CSF, GM-CSF, IFN $\alpha$, IFN $\gamma$, IL- $1 \alpha$, IL- $1 \beta$, IL-2, IL3, IL-4, IL-5, IL-7, IL-8, IL-10, IL-12(p40), IL-12(p70), IL-15, IP-10, TNF $\alpha$, and VEGF.

2.5. Immunofluorescence Microscopy. ALL and control MNC were fixed using 4\% paraformaldehyde and hydrated with PBS. Permeabilization was performed with $0.01 \%$ Triton X100 (Bio-Rad) and blocking with 2\% BSA for 30 minutes at $37^{\circ} \mathrm{C}$. Anti-pNF $\kappa \mathrm{B}$ p65 (serine 536) and anti-pSTAT3 (tyrosine 705) antibodies (Cell Signaling) were incubated for 1 hour at $37^{\circ} \mathrm{C}$ followed by incubation with goat anti-rabbit Alexa 488 (Invitrogen) antibody. Slides were mounted with Vectashield with propidium iodide (Vector). Overlay of images from the different fluorescent channels was performed using Image software (NHI) and Image Pro Plus software.

2.6. Purification of Precursor Cells. Mononuclear cells (MNC) from umbilical cord blood (UCB) were prepared by FicollPaque Plus (GE Healthcare Bioscience) gradient separation. $\mathrm{CD}_{3} 4^{+}$cells containing hematopoietic stem and progenitor cells were enriched from the MNC fraction using the Human CD34 Progenitor Cell Isolation Kit (Miltenyi Biotec) according to manufacturer instructions, with final purity frequencies between 85 and 95\%. Cells were enumerated before analyses, and the purity confirmed by flow cytometry.

2.7. CFSE Proliferation Assay. Carboxyfluorescein diacetate succinimidyl ester (CFSE) was used for in vitro labeling of cells to trace multiple generations using dye dilution by flow cytometry (Molecular Probes). CD $34^{+} \mathrm{CB}$ cells were incubated with $10 \mathrm{mM}$ CFSE and then exposed in a 120hour culture to supernatants collected from control BM MNC (Control SN), noninflammatory BM MNC (Non Infl SN), or inflammatory BM MNC (Infl SN). After the 5 days, harvested cells were analyzed by flow cytometry for their phenotype and the number of cell divisions. Dilution of fluorescence intensity to monitoring up to 8 cell divisions was estimated using the application for cell proliferation within the FlowJo 7.6.1 software.

2.8. Stromal Cell Co-Cultures. UCB precursor cells were placed on MS-5 stromal cell monolayers and cocultured with them for 3 weeks in the presence of ALL MNC supernatants and with lymphoid conditions, according to a modified previous report [26]. The $\alpha$-modified essential medium ( $\alpha$-MEM) was supplemented with $10 \%$ fetal bovine serum, $1 \mathrm{ng} / \mathrm{mL}$ Flt3-L (FL), $2 \mathrm{ng} / \mathrm{mL}$ SCF, $5 \mathrm{ng} / \mathrm{mL}$ IL-7, and $10 \mathrm{ng} / \mathrm{mL}$ IL15 (Preprotech) and contained $100 \mathrm{U} / \mathrm{mL}$ penicillin and $100 \mathrm{mg} / \mathrm{mL}$ streptomycin. Supernatants collected from control BM MNC (Control SN), noninflammatory BM MNC (Non Infl SN), or inflammatory BM MNC (Infl SN) were used in a $3: 1$ medium : supernatant volume ratio. Coculture systems were incubated at $37^{\circ} \mathrm{C}$ in a humidified atmosphere of $5 \% \mathrm{CO}_{2}$. Media and supernatants were weekly replaced. This controlled system promotes the efficient differentiation of hematopoietic stem, progenitor, and precursor cells towards B cells, NK cells, lymphoid-related dendritic cells, and some myeloid cells. Cell frequencies and final yield per input values were calculated on the basis of specific lineage production within each condition.

2.9. Proliferation and Differentiation Analyses by Flow Cytometry. Phenotyping of UCB hematopoietic cells from lymphoid cocultures was performed by six-color flow cytometry on a FACSCanto flow cytometer (BD Biosciences). Cells were enumerated after culture to calculate cell frequencies and yields per input progenitor prior to staining with directly conjugated fluorescent antibodies (Invitrogen and BD Pharmingen). For the CFSE proliferation assay, fluorochromeconjugated antibodies anti-lineage markers (CD3, CD8, TCR, CD56, CD14, CD11b, CD20, CD19, and CD235a) and antiCD34 were used to identify the $\mathrm{Lin}^{-} \mathrm{CD} 34^{+}, \mathrm{Lin}^{-} \mathrm{CD} 34^{-}$, and $\mathrm{Lin}^{+} \mathrm{CD} 34^{-}$populations. On the other hand, at the end of the differentiation cultures, harvested cells were stained with antibodies anti-CD34,-CD56,-CD11c, -CD19,-CD11b, and -CD14, and newly produced cells were identified by their phenotype as follows: stem and progenitor cell fraction as $\mathrm{CD} 34^{+}$; NK precursor cells as $\mathrm{CD} 34^{+} \mathrm{CD} 56^{+}$cells; $\mathrm{NK}$ cells as $\mathrm{CD} 4^{-} \mathrm{CD} 56^{+}$cells; dendritic cells as $\mathrm{CD}^{-11 c^{+}}$, and $\mathrm{B}$ cells as $\mathrm{CD} 19^{+}$, whereas myeloid cells were $\mathrm{CD} 11 \mathrm{~b}^{+} \mathrm{CD} 14^{-}$

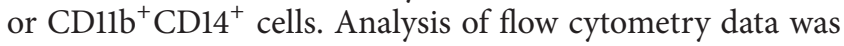
performed using the FlowJo 7.6.1 software, and final yield per input values was calculated on the basis of specific lineage cell frequencies within each condition.

2.10. Statistics. The Prism (version 5.01, GraphPad) and SPSS software were used for statistical analysis. Comparisons between groups were performed with the unpaired $t$-test. $P$ values were two-tailed and were considered significant if less than 0.05. Additionally, for the aberrant expression of myeloid markers, a distributional analysis of the data was made and found no normal distribution. Thus, comparison groups were performed with the nonparametric test $U$ MannWhitney, comparing the medians and taking $\alpha$ of $5 \%$ to define statistical significance.

\section{Results and Discussion}

3.1. Two Groups of B-ALL Patients according to BM Hematopoietic Cell Cytokine Production. The hematopoietic microenvironment within bone marrow (BM) is constituted by a cellular network and its products (including extracellular matrix, cytokines, chemokines, and growth factors), which 


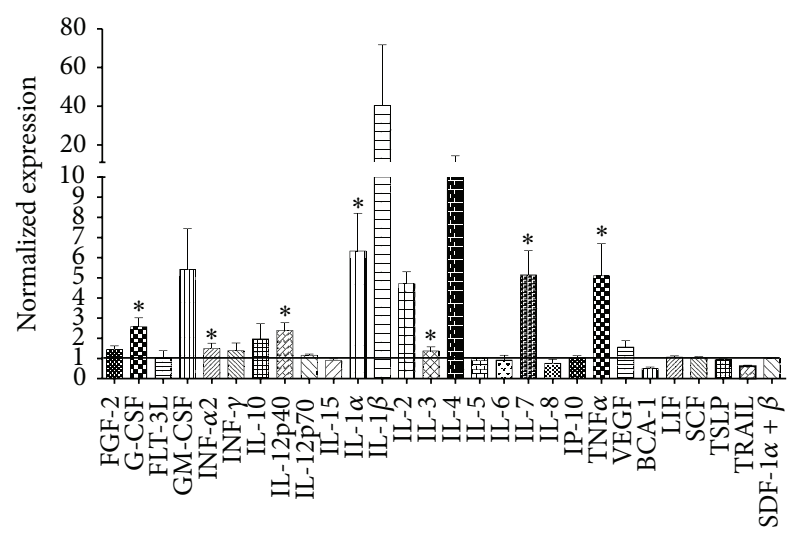

FIGURE 1: Bone marrow cells from childhood acute lymphoblastic leukemia produce proinflammatory cytokines and hematopoietic growth factors. ALL mononuclear cells from BM aspirates were cultured for $24 \mathrm{~h}$, and supernatants were further collected and assayed for 28 cytokines, chemokines, and growth factors. Normalized production relative to normal bone marrow cells was tabulated.

form a highly organized three-dimensional structure to support hematopoiesis $[12,29]$. Under normal conditions, the current model of hematopoietic microenvironment includes at least two specific cell niches, according to which stem cells require interaction with osteoblasts and endothelial cells, whereas the earliest progenitors are dependent on the contact with stromal cells expressing CXCL12/SDF1, and downstream lineage committed precursors of B cells require IL-7. The recent discovery of regulation of the hematopoietic developmental pathways by pathogen and/or danger recognition by primitive cells suggests that Toll-like receptors (TLR) are involved in the early cell fate decisions and contribute to the emergent replenishment of innate hematopoietic cells in the context of inflammatory settings [13, 30-38]. Moreover, the production of proinflammatory cytokines and growth factors, including TNF $\alpha$, IL-12, IL-3, IL-6, IL-8, GM-CSF, and MCP-1, as a result of TLR signaling in normal progenitor cells, has been documented [37,39-41]. In response to these inflammatory signals, hematopoietic stem and early progenitors can, in turn, produce cytokines that promote their mobilization and expedite differentiation to innate cells $[42,43]$.

Derived from the tumor microenvironment, leukemic cells have been shown to harm normal biology of hematopoietic cells [22]. Therefore, cytokines and growth factors were now quantified in supernatants derived from B-ALL MNC. Remarkably, the proinflammatory factors IL- $1 \alpha$, IL- $1 \beta$, and $\mathrm{TNF} \alpha$ were highly overproduced when compared to production levels by their normal counterpart, with up to 40time increases for IL-1 $\beta$ (Figure 1). Moreover, some cytokines, interferons, and growth factors participating in inflammatory responses, including G-CSF, GM-CSF, IFN $\alpha$, and IL-12 were substantially elevated in B-ALL. The same was true for early lymphoid-related growth factors, like IL-7 (Figure 1). Thus, for the first time, hematopoietic precursors in childhood B-cell acute lymphoblastic leukemia have been shown to produce proinflammatory and hematopoietic growth soluble factors. Modest increments were observed in IFN $\gamma$, IL-10, and VEGF, while no changes were registered in Flt3L, IL-15, IL-5, IL-6, IL-8, SCF, and SDF-1. Accordingly, although the evaluation of cytokines and growth factors in patients with acute lymphoblastic leukemia has been achieved mostly in serum and plasma specimens, a couple of relevant reports indicate their production by leukemic blasts in the bone marrow [44-47], supporting the notion that malignant cells directly contribute to the pathogenesis of ALL by creating an inflammatory microenvironment.

It remains to be seen whether the cytokine production in B-ALL results from a response to TLR ligation by pathogenassociated or damage-associated molecular patterns (PAMPs or DAMPs, resp.) $[13,37]$ or from a genetic aberration leading to a constitutive activation of inflammatory pathways [28]. As we have additionally found a significant production of inflammatory cytokines plus IL-6 by BM mesenchymal stromal cells (MSC) from B-ALL (unpublished data), we assume that some extrinsic stimuli may contribute to a bystander release of hematopoietic cytokines through activation of MSC [48].

Despite the heterogeneity in the abundance of the produced cytokines among patients, analyses of data dispersion indicated the existence of two groups, defined according to concentration of the produced cytokines upon $24 \mathrm{~h}$ culture (Figure 2(a)). Strikingly, a distinct and minor group behaved differently from most patients and from the normal controls, as they produced the highest amount of growth factors, interferons, and proinflammatory factors. Supernatants derived from this minor group and containing proinflammatory factors were designated as "inflammatory supernatants," whereas supernatants containing low or normal amounts of proinflammatory factors were considered "noninflammatory supernatants." Normal supernatants were derived from BM mononuclear cells from nonhematological individuals.

To explore the possibility of a local and transient cell preactivation, cell cultures were continued for additional $24 \mathrm{~h}$ upon the former supernatant collection. Concentration graphs in Figure 2(b) suggest a long-term activation of inflammatory pathways, independent on the continuous stromal cell contact within BM.

In order to investigate the pathways involved in the triggering of proinflammatory microenvironment, the activation status of p65 NFא B and STAT3 was examined by indirect immunofluorescence (Figure 3). Among patients, the heterogeneity in activation levels of these transcription factors was a constant. However, samples showing a proinflammatory profile were mostly positive for phosphorylated $\mathrm{NF} \kappa \mathrm{B}$ and STAT3, suggesting that, in this group of patients, the proinflammatory property is apparently mediated by the activation of NF $\kappa$ B and STAT3 pathways (Figure 3, top panel). In contrast, BM samples identified as noninflammatory showed much less activation of both $\mathrm{NF} \kappa \mathrm{B}$ and STAT3, and their normal counterpart shows scant basal activation. Interestingly, these transcription factors cooperate to promote the development and progression of cancer, and inhibitors of NF $\kappa \mathrm{B}$ and STAT3 have been proposed as therapeutically useful in switching the inflammatory nature of tumor environments. After activating their signaling pathways, 

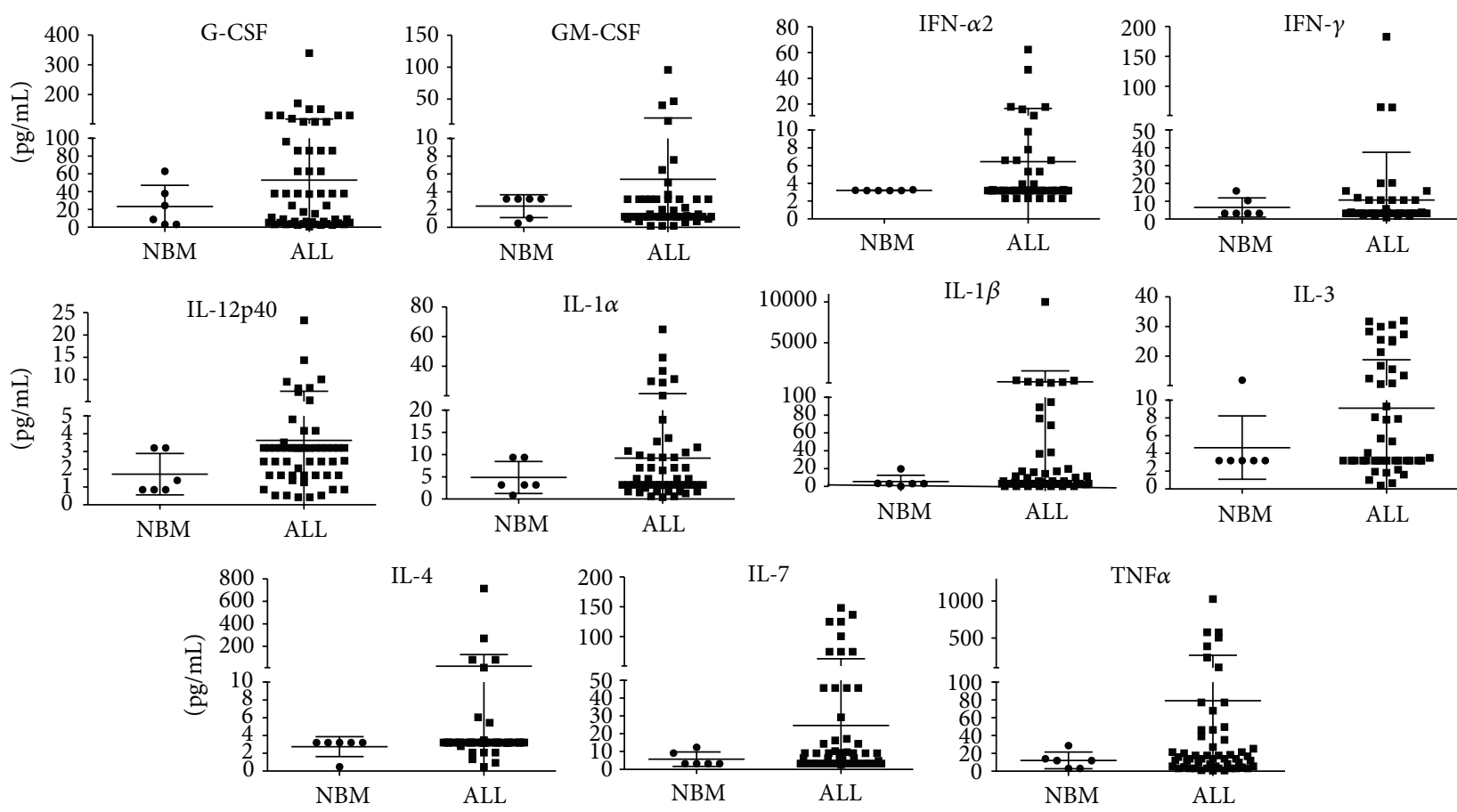

(a)
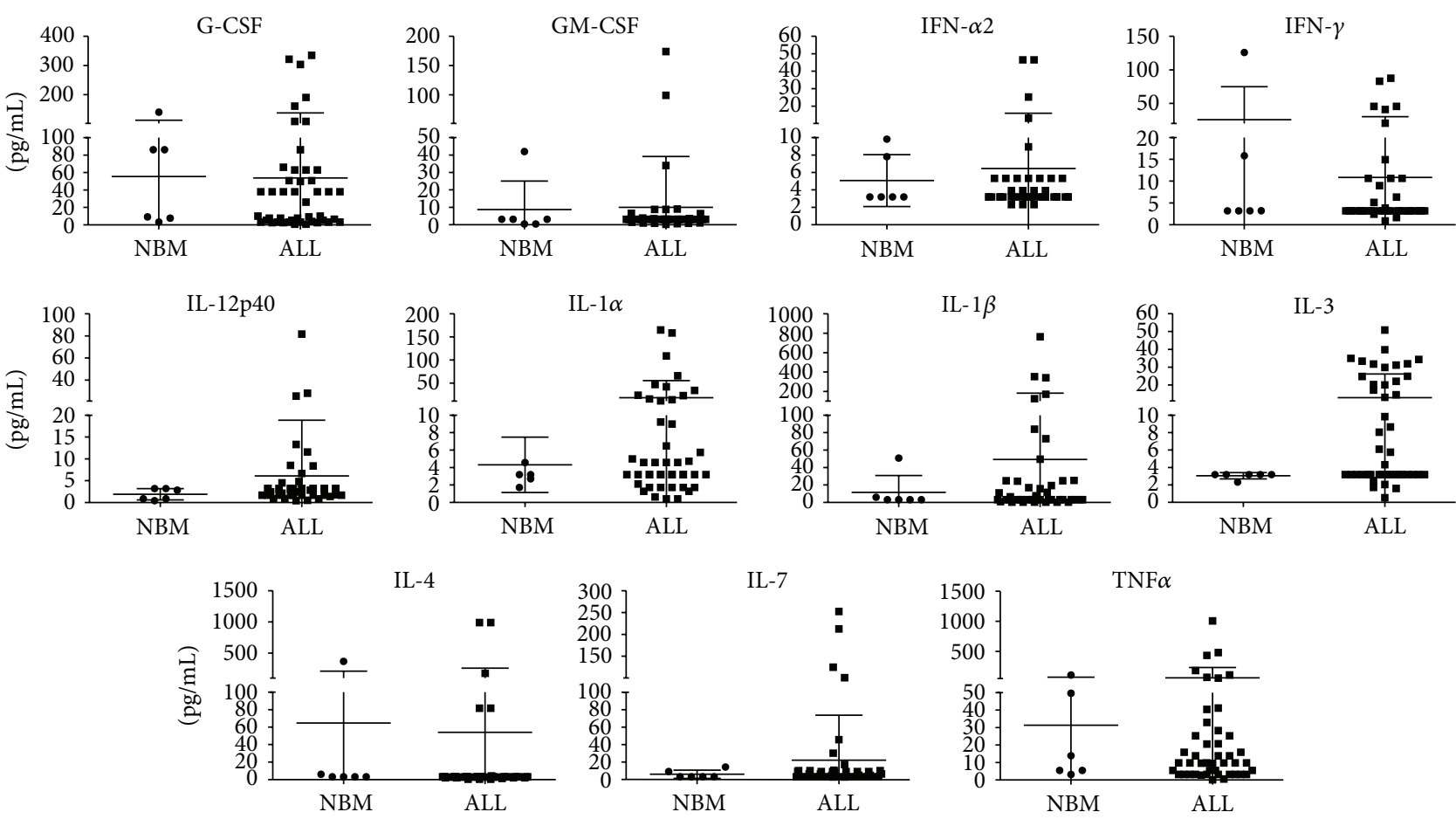

(b)

FIGURE 2: A distinct group of patients is highly producer of proinflammatory cytokines and hematopoietic growth factors. ALL or normal BM (NBM) mononuclear cells were cultured for $24 \mathrm{~h}$ (a) and supernatants immediately collected. Cells were provided with additional culture medium and supernatants collected $24 \mathrm{~h}$ later (b). The distribution of highly produced cytokines in NBM and ALL patients is shown. 


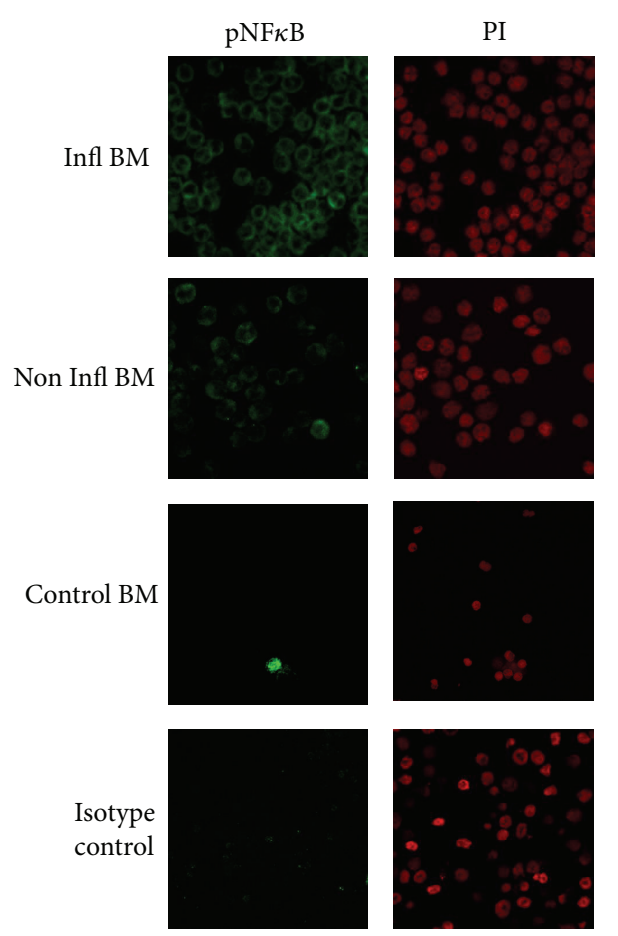

(a)
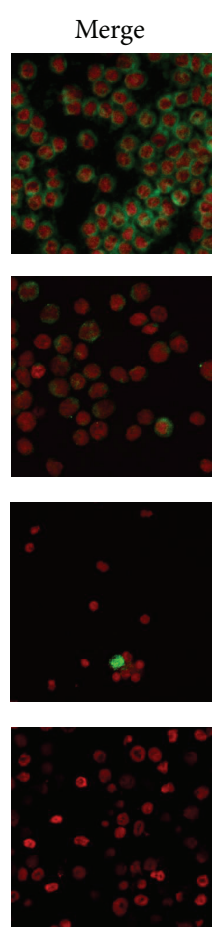

pSTAT3
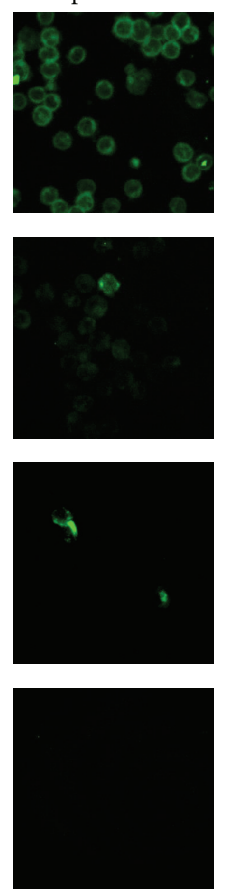

PI
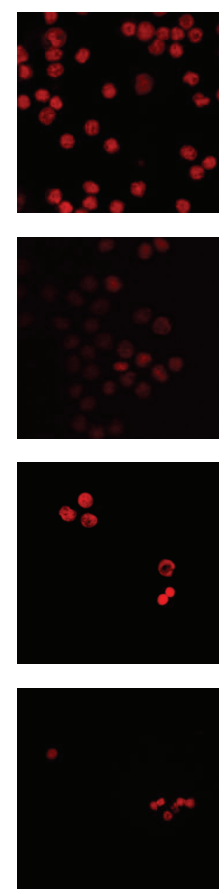

(b)
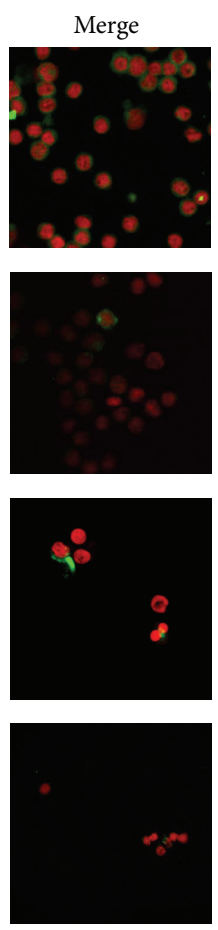

FIGURE 3: A proinflammatory profile is associated with activation of NF $\kappa$ B and STAT3. Immunofluorescence microscopy was used to demonstrate $\mathrm{pNF} \kappa \mathrm{B}$ p 65 and pSTAT3 transcription factors within MNC fractions from ALL patients showing a proinflammatory profile (Infl $\mathrm{BM}$ ) and a noninflammatory profile (Non Infl) or from normal individuals (Control BM). Propidium iodide was used for nuclear staining. A representative figure of four independent experiments is shown.

the expression of antiapoptotic and proproliferative genes is under their control in both neoplastic and normal tissues $[1,49]$. Moreover, studies indicate that leukemic stem cells in acute myelogenous leukemia have constitutively activated $\mathrm{NF} \kappa \mathrm{B}$ [28], while STAT3 participates in the maintenance and self-renewal of HSC in TEL-AML1 t(12:21) ALL [50] and helps in the rebounding of the hematopoietic system through the control of myeloid progenitors differentiation [51].

\subsection{The Inflammatory Profile Is Related to B-ALL BM Coex-} pressing Myeloid Markers. Among the 54 ALL patients included in this study, 34 fulfilled the criteria for highrisk disease by blood cell count, age, or $\mathrm{Ph}+$ chromosome, whereas 17 fulfilled the criteria for standard-risk (Table 1). The median age values were 7.8 year old $(2 \mathrm{mo}-18 \mathrm{yr})$ and 4.8 $(2 \mathrm{yr}-9 \mathrm{yr})$ for the high-risk and standard-risk group, respectively. Independent of the conventional risk stratification, 20 patients showed aberrant coexpression of one or more myeloid markers, including CD13 and CD33.

Correlation tests were conducted by the Pearson method (not shown), showing weak or absent associations between risk stratification groups (Table 1) and the production of proinflammatory cytokines. No associations were found neither between single lymphoid markers (CD10, CD19, or CD20) or coexpressed single myeloid markers (CD13, CD14, $\mathrm{CD} 15$, or CD33) with production of particular cytokines. However, when the studied population was classified according to concomitant coexpression of 3 lymphoid markers
(CD10, CD19, and CD20) or the aberrant expression of the myeloid markers $\mathrm{CD} 13$ and $\mathrm{CD} 33$, four groups were identified: a $\mathrm{CD} 10+\mathrm{CD} 19+\mathrm{CD} 20+$ positive group, which coexpressed these 3 B-lymphoid markers; a group lacking concomitant expression of CD10, CD19, and CD20, but expressing less than 3 of these B-lymphoid markers (CD10+/-CD19+/-CD20+/-) (Table 2); a CD13+CD33+ positive group; and a group expressing less than these 2 myeloid markers (Table 3). First, Mann-Whitney test was applied after the Kolmogorov-Smirnov analysis to discard normal distribution, and significant differences between the lymphoid positive $(\mathrm{CD} 10+\mathrm{CD} 19+\mathrm{CD} 20+)$ and negative (CD10+/-CD19+/-CD20+/-) groups were found for IL-1 $\beta$, TNF- $\alpha$, G-CSF, and IFN- $\alpha 2$ with $P \leq 0.05$ (Table 2). On the other hand, patients with aberrant coexpression of $\mathrm{CD} 13$ and $\mathrm{CD} 33$ in more than $25 \%$ of BM MNC were considered as a positive group in Table 3. Strikingly, $U$ MannWhitney test showed significant differences between the two myeloid groups for IL- $1 \alpha$, IL-1 $\beta$, IL-12p 40 , TNF- $\alpha$, and GMCSF (Table 3). Thus, aberrant expressions of myeloid markers within B-ALL BM apparently condition the abnormal production of proinflammatory factors. It remains to be investigated whether cells expressing myeloid markers constitute the origin of these factors, or they function as target and respond to proinflammatory factors by upregulating myeloid-related molecules. Alternatively, they might be newly differentiated under the emergency settings of ALL [42, 43, 48]. 
TABle 1: Patient characteristics.

\begin{tabular}{|c|c|c|c|c|c|c|c|}
\hline Patient & Age (yr) & Sex & $\mathrm{WBC} / \mathrm{mm}^{2}$ & Phenotype & $\begin{array}{c}\text { Risk stratification } \\
\text { Risk factor }\end{array}$ & $\begin{array}{c}\text { Aberrant expression } \\
\text { of myeloid markers }\end{array}$ & $\begin{array}{c}\text { Concomitant expression } \\
\text { of CD10/CD19/CD20 }\end{array}$ \\
\hline 1 & 4 & $\mathrm{~F}$ & 33700 & B-ALL & SR & NEG & POS \\
\hline 2 & 4 & $\mathrm{~F}$ & 7600 & B-ALL & SR & CD15 & POS \\
\hline 3 & 11 & $\mathrm{~F}$ & 65000 & B-ALL & $\begin{array}{c}\text { HR } \\
\text { Leukocytosis }\end{array}$ & NEG & POS \\
\hline 4 & 4 & $\mathrm{M}$ & 26400 & B-ALL & SR & CD13/CD33 & NEG \\
\hline 5 & 11 & M & 36600 & B-ALL & $\begin{array}{l}\text { HR } \\
\text { Age } \\
\end{array}$ & CD13/CD33 & NEG \\
\hline 6 & 5 & M & 23000 & B-ALL & $\begin{array}{c}\mathrm{HR} \\
\mathrm{PhCr}+\end{array}$ & $\mathrm{CD} 13$ & POS \\
\hline 7 & 5 & $\mathrm{M}$ & 8900 & T-ALL & $\begin{array}{c}\text { HR } \\
\text { T-ALL }\end{array}$ & NEG & POS \\
\hline 8 & 2 & $\mathrm{~F}$ & 91500 & B-ALL & $\begin{array}{c}\text { HR } \\
\text { Leukocytosis } \\
\text { PhCr+ } \\
\end{array}$ & NEG & POS \\
\hline 9 & 1 & M & 40000 & B-ALL & $\begin{array}{l}\text { HR } \\
\text { Age } \\
\end{array}$ & NEG & $\mathrm{NEG}$ \\
\hline 10 & 10 & $\mathrm{~F}$ & 1500 & B-ALL & $\begin{array}{l}\mathrm{HR} \\
\text { Age }\end{array}$ & NEG & POS \\
\hline 11 & 12 & $\mathrm{~F}$ & 1300 & B-ALL & $\begin{array}{l}\text { HR } \\
\text { Age }\end{array}$ & $\mathrm{CD} 13 / \mathrm{CD} 15$ & NEG \\
\hline 12 & 2 & $\mathrm{M}$ & 39000 & B-ALL & $\mathrm{SR}$ & NEG & POS \\
\hline 13 & 5 & $\mathrm{M}$ & 11400 & B-ALL & SR & NEG & NEG \\
\hline 14 & 13 & M & 3400 & B-ALL & $\begin{array}{l}\mathrm{HR} \\
\text { Age }\end{array}$ & NEG & $\mathrm{NEG}$ \\
\hline 15 & 5 & $\mathrm{M}$ & 1100 & B-ALL & SR & $\mathrm{CD} 13$ & NEG \\
\hline 16 & 2 & M & 5300 & B-ALL & SR & NEG & NEG \\
\hline 17 & 3 & $\mathrm{~F}$ & 260000 & B-ALL & $\begin{array}{c}\mathrm{HR} \\
\mathrm{PhCr}+\end{array}$ & $\mathrm{CD} 13$ & NEG \\
\hline 18 & 3 & $\mathrm{M}$ & 85700 & B-ALL & $\begin{array}{c}\text { HR } \\
\text { Leukocytosis }\end{array}$ & $\mathrm{CD} 13$ & NEG \\
\hline 19 & 4 & $\mathrm{M}$ & 161500 & B-ALL & $\mathrm{HR}$ & NEG & POS \\
\hline 20 & 13 & $\mathrm{M}$ & 1600 & M-ALL & HR & $\mathrm{CD} 13 / \mathrm{MPO}$ & NEG \\
\hline 21 & 13 & $\mathrm{M}$ & 2600 & B-ALL & $\begin{array}{c}\text { HR } \\
\text { Leukocytosis }\end{array}$ & NEG & NEG \\
\hline 22 & 3 & $\mathrm{M}$ & 400500 & T-ALL & $\begin{array}{c}\text { HR } \\
\text { T-ALL }\end{array}$ & NEG & NEG \\
\hline 23 & 3 & M & 52500 & B-ALL & $\begin{array}{c}\text { HR } \\
\text { Leukocytosis }\end{array}$ & CD-13 & NEG \\
\hline 24 & 3 & $\mathrm{~F}$ & 35100 & B-ALL & $\mathrm{SR}$ & CD15 & NEG \\
\hline 25 & 10 & $\mathrm{M}$ & 3500 & B-ALL & SR & NEG & NEG \\
\hline 26 & 10 & $\mathrm{~F}$ & 1200 & B-ALL & $\begin{array}{l}\text { HR } \\
\text { Age }\end{array}$ & CD13/CD15 & NEG \\
\hline 27 & 6 & M & 115000 & B-ALL & $\begin{array}{c}\text { HR } \\
\text { Leukocytosis } \\
\end{array}$ & $\mathrm{CD} 13$ & NEG \\
\hline 28 & 2 & $\mathrm{M}$ & - & B-ALL & - & NEG & POS \\
\hline 29 & 6 & M & 131000 & B-ALL & $\begin{array}{l}\text { HR } \\
\text { Age } \\
\end{array}$ & CD13 & NEG \\
\hline 30 & 6 & $\mathrm{M}$ & 83500 & B-ALL & $\begin{array}{c}\text { HR } \\
\text { Leukocytosis }\end{array}$ & NEG & POS \\
\hline 31 & 3 & $\mathrm{~F}$ & 2700 & B-ALL & $\mathrm{SR}$ & NEG & POS \\
\hline 32 & 6 & $\mathrm{M}$ & 13100 & B-ALL & SR & NEG & POS \\
\hline
\end{tabular}


TABle 1: Continued.

\begin{tabular}{|c|c|c|c|c|c|c|c|}
\hline Patient & Age (yr) & Sex & $\mathrm{WBC} / \mathrm{mm}^{2}$ & Phenotype & $\begin{array}{c}\text { Risk stratification } \\
\text { Risk factor }\end{array}$ & $\begin{array}{l}\text { Aberrant expression } \\
\text { of myeloid markers }\end{array}$ & $\begin{array}{c}\text { Concomitant expression } \\
\text { of CD10/CD19/CD20 }\end{array}$ \\
\hline 33 & 6 & $\mathrm{M}$ & 12600 & B-ALL & SR & NEG & NEG \\
\hline 34 & 3 & $\mathrm{M}$ & 15600 & B-ALL & SR & NEG & POS \\
\hline 35 & 4 & $\mathrm{~F}$ & - & B-ALL & - & NEG & NEG \\
\hline 36 & 6 & $\mathrm{M}$ & 1000 & B-ALL & SR & NEG & NEG \\
\hline 37 & 14 & $\mathrm{~F}$ & 600 & B-ALL & $\begin{array}{c}\mathrm{HR} \\
\mathrm{PhCr}+\end{array}$ & NEG & NEG \\
\hline 38 & 14 & M & 163000 & B-ALL & $\begin{array}{c}\text { HR } \\
\text { Leukocytosis }\end{array}$ & NEG & POS \\
\hline 39 & 10 & M & 5900 & B-ALL & $\begin{array}{l}\text { HR } \\
\text { Age }\end{array}$ & CD13 & POS \\
\hline 40 & 4 & M & 16100 & B-ALL & $\begin{array}{c}\mathrm{HR} \\
\mathrm{PhCr}+\end{array}$ & NEG & NEG \\
\hline 41 & 15 & M & 113000 & B-ALL & $\begin{array}{c}\text { HR } \\
\text { Age } \\
\text { Leukocytosis }\end{array}$ & NEG & NEG \\
\hline 42 & 6 & $\mathrm{M}$ & 42100 & B-ALL & SR & NEG & NEG \\
\hline 43 & 15 & M & 47400 & B-ALL & $\begin{array}{l}\text { HR } \\
\text { Age }\end{array}$ & NEG & NEG \\
\hline 44 & 9 & M & 185000 & B-ALL & $\begin{array}{c}\text { HR } \\
\text { Leukocytosis }\end{array}$ & NEG & POS \\
\hline 45 & 7 & $\mathrm{M}$ & 4000 & B-ALL & SR & CD13 & NEG \\
\hline 46 & 17 & M & - & B-ALL & $\begin{array}{l}\text { HR } \\
\text { Age }\end{array}$ & NEG & NEG \\
\hline 47 & 0.9 & $\mathrm{~F}$ & 334700 & B-ALL & $\begin{array}{l}\text { HR } \\
\text { Age }\end{array}$ & CD33 & POS \\
\hline 48 & 1 & $\mathrm{~F}$ & 87900 & B-ALL & $\begin{array}{c}\text { HR } \\
\text { Leukocytosis }\end{array}$ & NEG & POS \\
\hline 49 & 7 & $\mathrm{M}$ & 10500 & B-ALL & SR & CD13/CD15 & NEG \\
\hline 50 & 8 & $\mathrm{M}$ & - & B-ALL & - & CD15 & NEG \\
\hline 51 & 9 & $\mathrm{M}$ & 1900 & B-ALL & HR & NEG & NEG \\
\hline 52 & 0.4 & $\mathrm{~F}$ & 41600 & B-ALL & $\begin{array}{l}\text { HR } \\
\text { Age }\end{array}$ & $\mathrm{CD} 13$ & NEG \\
\hline 53 & 8 & $\mathrm{~F}$ & 52500 & B-ALL & $\begin{array}{c}\text { HR } \\
\text { Leukocytosis }\end{array}$ & NEG & NEG \\
\hline 54 & 8 & $\mathrm{~F}$ & 350000 & B-ALL & $\begin{array}{c}\text { HR } \\
\text { Leukocytosis }\end{array}$ & NEG & POS \\
\hline
\end{tabular}

yr: years old; WBC: white blood cell count; M: male; F: female; B-ALL: B-cell precursor acute lymphoblastic leukemia; T-ALL: T-cell acute lymphoblastic leukemia; M-ALL: mixed acute leukemia; HR: high risk; SR: standard risk.

3.3. Early Progenitor Cells Are Driven into Cycle by Inflammatory Factors in $B$-ALL. CFSE dilution assays were performed to test progenitor cell responses to inflammatory factors produced by the subset of cases of ALL expressing the myeloid antigens CD13 and CD33 within BM (Figure 4). Moderate acceleration of lineage commitment from $\mathrm{Lin}^{-} \mathrm{CD} 34^{+}$to $\mathrm{Lin}^{+} \mathrm{CD} 34^{-}$stages was recorded when multiparametric flow cytometry was used for phenotyping of the newly produced cells upon 5-day culture in lymphoid conditions (Figure 4(a)). In contrast, the induction to cell proliferation states by noninflammatory and inflammatory supernatants was clear (Figures 4(b) and 4(c)). While there was no apparent influence on the earliest cell compartment by noninflammatory factors, the differentiating $\mathrm{Lin}^{-} \mathrm{CD} 34^{-}$ stage was selectively prompt to proliferate. Of special interest, inflammatory conditions clearly showed the awakening of primitive cells (Figure 4(c), left panel), as well as an intense activity on more differentiated $\mathrm{Lin}^{-} \mathrm{CD} 34^{-}$and $\mathrm{Lin}^{+} \mathrm{CD} 34^{-}$ cells. The net positive effect was most appreciated when total absolute cell numbers of each particular stage were analyzed with respect to cell divisions (Figure 4(d)). Progenitor cells were driven into cycle by inflammatory conditions, as seen in the transition from cell generation $0(\mathrm{G} 0)$ to generation 1 (G1) and downstream to generation 2 (G2). The promotion effect was also observed in differentiating Lin $^{-} \mathrm{CD} 34^{-}$cells, where most cell generations from G1 to G6 contained mainly cells from the inflammatory condition (Figure 4, middle panel). In contrast, developing mature cells were restrictively promoted to proliferate up to G2 and in a similar extent as under noninflammatory conditions. According to these observations, previous reports indicate that during chronic inflammation, awakening of stem and progenitor cells leads to exhaustion of the pool $[32,34,52]$. Deciphering if the same is true for normal hematopoietic cells within ALL BM will 
TABLE 2: BM-expressing less than 3 B-ALL lymphoid markers produce high levels of proinflammatory factors.

\begin{tabular}{|c|c|c|c|}
\hline Cytokine & $\begin{array}{c}\text { Expression of } 3 \text { lymphoid markers } \\
(\mathrm{CD} 10+\mathrm{CD} 19+\mathrm{CD} 20+) \\
\text { Median }(\mathrm{pg} / \mathrm{mL}) \\
\text { IR }\end{array}$ & $\begin{array}{c}\text { Less than } 3 \text { positive lymphoid markers } \\
(\mathrm{CD} 10+/-\mathrm{CD} 19+/-\mathrm{CD} 20+/-) \\
\text { Median }(\mathrm{pg} / \mathrm{mL}) \\
\text { IR }\end{array}$ & $P$ \\
\hline IL- $1 \alpha$ & $\begin{array}{l}3.20 \\
4.07\end{array}$ & $\begin{array}{r}4.58 \\
9.20\end{array}$ & 0.202 \\
\hline IL-1 $\beta$ & $\begin{array}{l}3.20 \\
6.90 \\
\end{array}$ & $\begin{array}{c}10.00 \\
8.80\end{array}$ & $0.004^{* *}$ \\
\hline IL-12p40 & $\begin{array}{l}2.44 \\
2.20\end{array}$ & $\begin{array}{l}3.00 \\
2.83\end{array}$ & 0.167 \\
\hline TNF $\alpha$ & $\begin{array}{c}9.85 \\
13.72\end{array}$ & $\begin{array}{l}19.00 \\
54.73\end{array}$ & $0.032^{*}$ \\
\hline G-CSF & $\begin{array}{c}9.00 \\
45.92\end{array}$ & $\begin{array}{c}37.93 \\
102.38\end{array}$ & $0.049^{*}$ \\
\hline GM-CSF & $\begin{array}{l}3.00 \\
0.45\end{array}$ & $\begin{array}{l}3.20 \\
1.22\end{array}$ & 0.08 \\
\hline IL-7 & $\begin{array}{l}5.00 \\
6.39\end{array}$ & $\begin{array}{c}9.18 \\
42.51\end{array}$ & 0.104 \\
\hline IFN- $\alpha 2$ & $\begin{array}{l}0.700 \\
0.700\end{array}$ & $\begin{array}{l}2.20 \\
3.80\end{array}$ & $0.008^{* *}$ \\
\hline
\end{tabular}

${ }^{*} P=0.05 ;{ }^{* *} P=0.001$.

Concomitant expression of CD10, CD19, and CD20. U-Mann Whitney test; IR: interquartile range; CMN: mononuclear cells.

TABLE 3: Aberrant expression of myeloid markers in B-ALL and production of proinflammatory factors.

\begin{tabular}{|c|c|c|c|}
\hline Cytokine & $\begin{array}{c}\text { Expression of the myeloid markers } \\
\text { CD13 and CD33 } \\
\text { Median }(\mathrm{pg} / \mathrm{mL}) \\
\text { IR }\end{array}$ & $\begin{array}{c}\text { Expression of less than two myeloid markers } \\
\text { (CD13 or CD33) } \\
\text { Median (pg/mL) } \\
\text { IR }\end{array}$ & $P$ \\
\hline IL- $1 \alpha$ & $\begin{array}{l}46.00 \\
52.38\end{array}$ & $\begin{array}{r}3.20 \\
96.39\end{array}$ & $0.009^{* *}$ \\
\hline IL- $1 \beta$ & $\begin{array}{l}429.00 \\
9911.00\end{array}$ & $\begin{array}{c}3.20 \\
13.96\end{array}$ & $0.008^{* *}$ \\
\hline IL-12p40 & $\begin{array}{l}8.00 \\
6.80\end{array}$ & $\begin{array}{l}3.00 \\
1.53 \\
\end{array}$ & $0.051^{*}$ \\
\hline TNF $\alpha$ & $\begin{array}{l}237.00 \\
342.49 \\
\end{array}$ & $\begin{array}{l}13.92 \\
22.14\end{array}$ & $0.022^{*}$ \\
\hline G-CSF & $\begin{array}{c}37.00 \\
104.17\end{array}$ & $\begin{array}{l}24.32 \\
81.19\end{array}$ & 0.558 \\
\hline GM-CSF & $\begin{array}{l}7.00 \\
1.69 \\
\end{array}$ & $\begin{array}{l}3.20 \\
0.20 \\
\end{array}$ & $0.015^{*}$ \\
\hline IL-7 & $\begin{array}{l}17.00 \\
36.71 \\
\end{array}$ & $\begin{array}{c}6.00 \\
12.80\end{array}$ & 0.222 \\
\hline INF $\alpha 2$ & $\begin{array}{c}8.00 \\
12.80\end{array}$ & $\begin{array}{l}3.20 \\
3.80\end{array}$ & 0.122 \\
\hline
\end{tabular}

${ }^{*} P=0.05 ;{ }^{* *} P=0.001$.

Concomitant expression of CD13 and CD33. U-Mann Whitney test; IR: interquartile range.

be highly relevant and may help to predict risk or protective scenarios.

3.4. A Proinflammatory Environment of ALL BM Prompts Normal Hematopoietic Differentiation. To determine whether the ALL-inflammatory setting could influence early hematopoietic progenitor cell fate decisions, $\mathrm{Lin}^{-} \mathrm{CD} 34^{+}$cells from UCB were purified, exposed to normal or ALL supernatants, and cultured during 3 weeks under lymphoid conditions. Further cell harvesting revealed that CD34, NK, B, DC, and myeloid cell production were substantially increased by
ALL-derived inflammatory supernatants when compared to normal controls. At the end of coculture, CB lymphoid progenitors showed at least twice yield per input progenitor upon incubation with ALL-factors (Figure 5). Of particular interest was the overproduction of innate immune $\mathrm{NK}$ and $\mathrm{CD} 14^{+}$ myeloid cells, which resemble the stem and progenitor cell behavior under stress conditions or threatening infections $[13,32,37,43]$.

The function of some soluble factors is fundamental within the tumor microenvironment: TNF $\alpha$ potentiates growth of malignant skin, ovarian, and pancreatic tumors and 

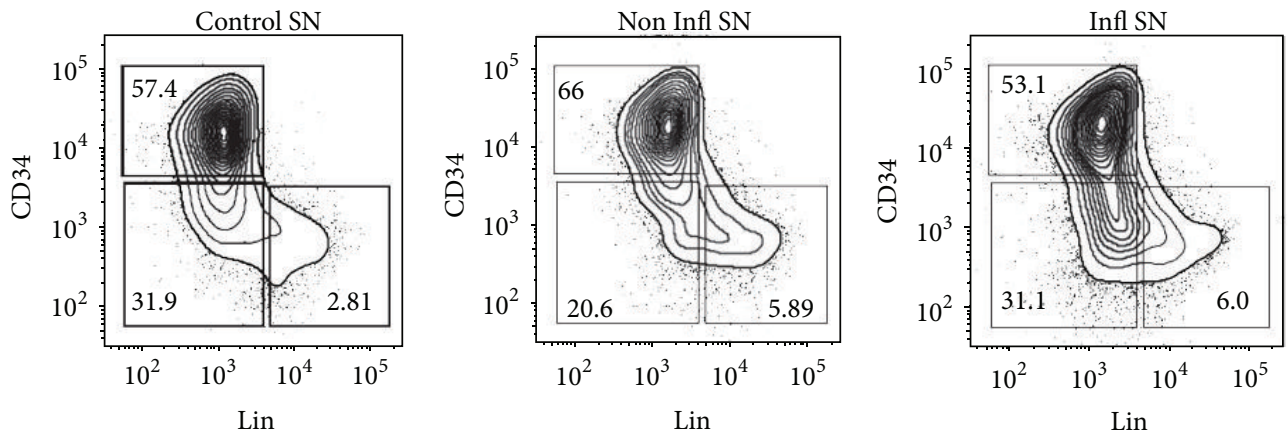

(a)
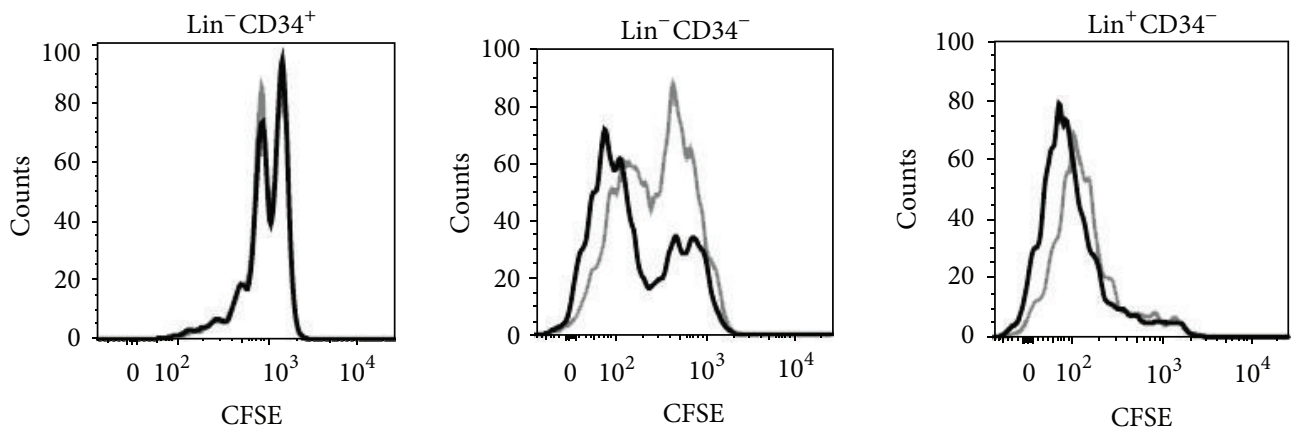

- Control SN

- Non Infl SN

- Control SN

- Non Infl SN

- Control SN

- Non Infl SN

(b)
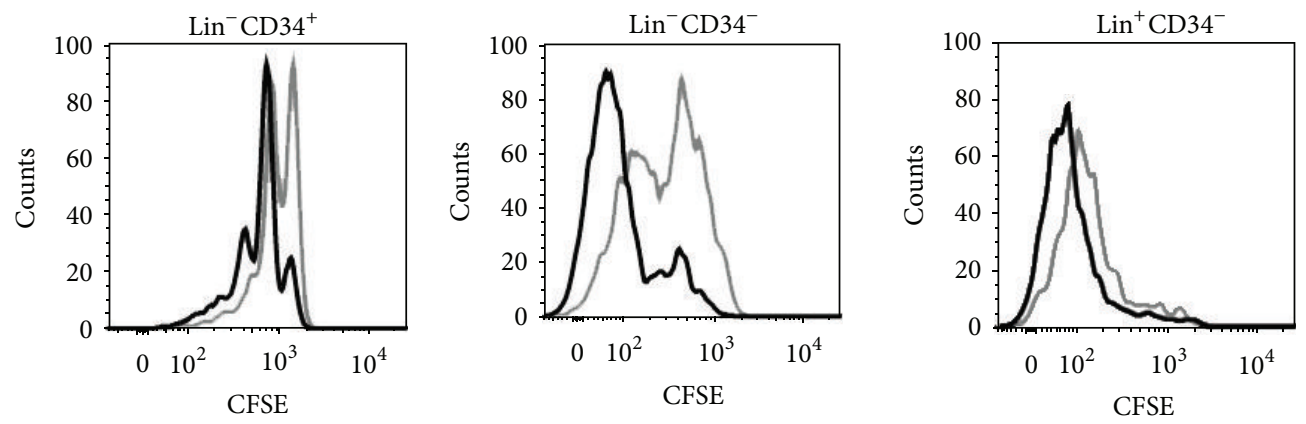

- Control SN

- Infl SN

- Control SN

- Infl SN

- Control SN

- Infl SN

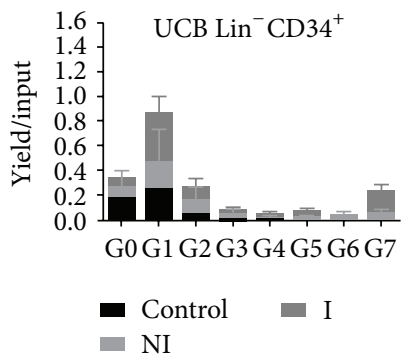

(c)
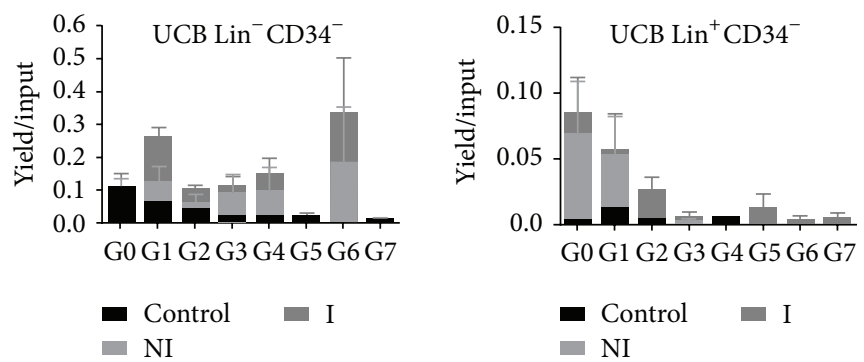

(d)

FIGURE 4: Proinflammatory factors produced by hematopoietic ALL BM cells promote the proliferation of normal primitive cells. Umbilical cord blood $\mathrm{CD}_{3} 4^{+}$cells were purified by magnetic separation and analyzed for their proliferation capabilities after $120 \mathrm{~h}$ exposure to control, noninflammatory, and inflammatory supernatants. The indicated gates were used to determine cell frequencies within the culture for Lineage ${ }^{-} \mathrm{CD} 34^{+}$primitive cells, Lineage ${ }^{-} \mathrm{CD} 34^{-}$differentiating precursor cells, and Lineage ${ }^{+} \mathrm{CD} 34^{-}$maturing cells (a) and to examine the number of cell divisions within each population. Exposure of cells to noninflammatory supernatants is shown in (b), whereas the inflammatory culture conditions are shown in (c). Total cell numbers within each cell generation and from each treatment condition were calculated and expressed as yields per input progenitor (d). Analyses of cell divisions (expressed as number of cell generations) were performed using the FlowJo software. Representative data of two independent experiments. 

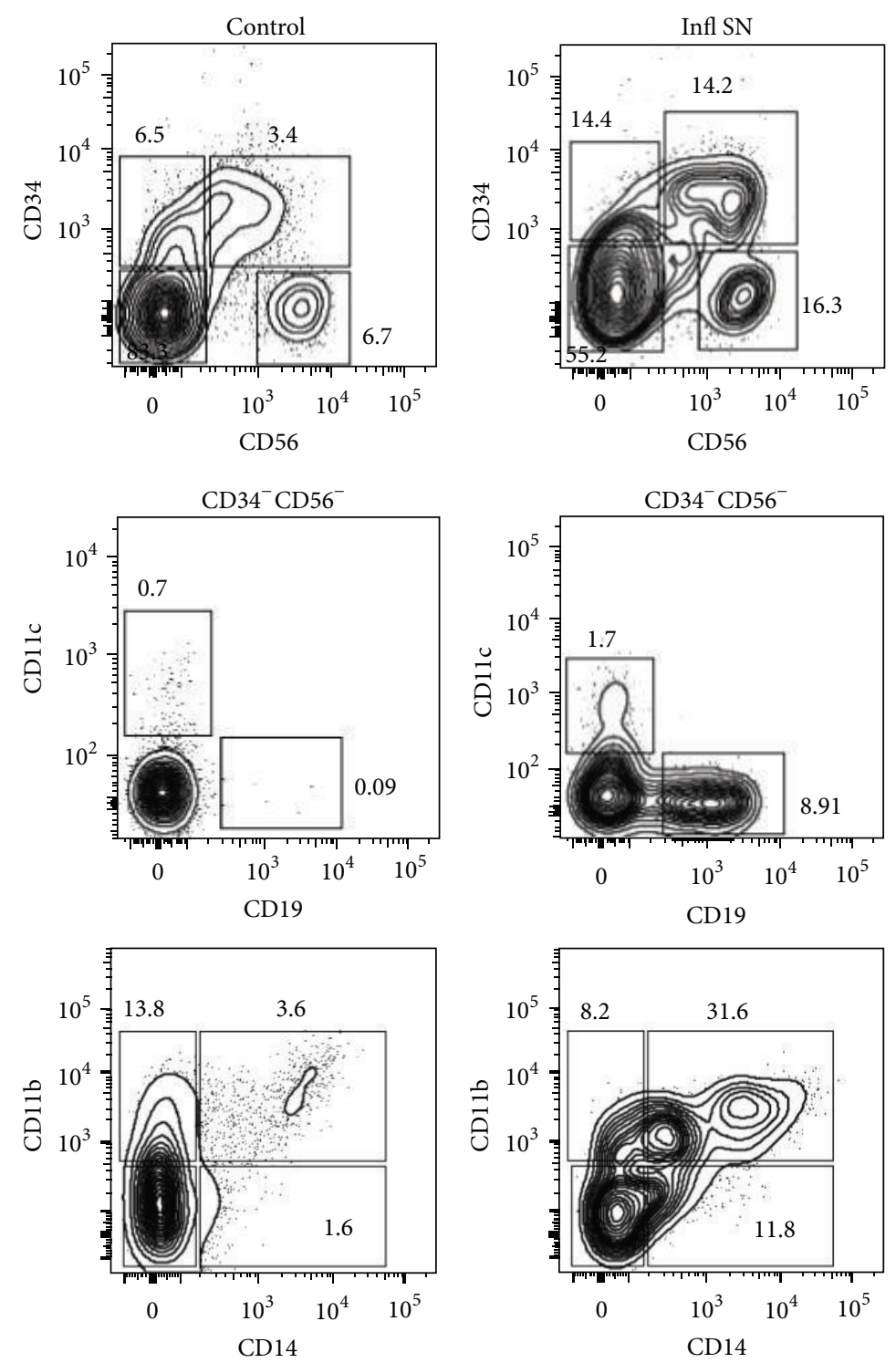

(a)
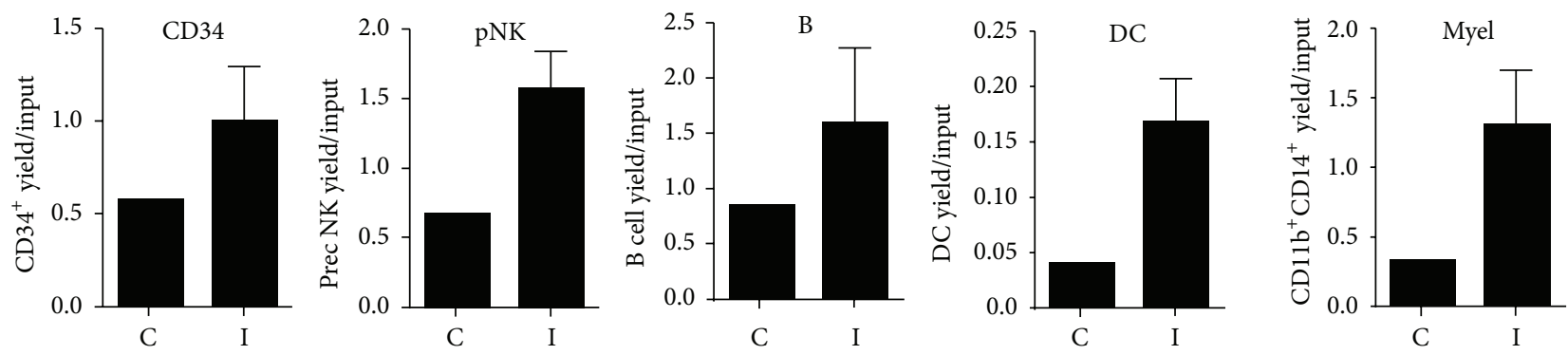

(b)

FIGURE 5: Early lymphoid- and myeloid-cell differentiation is substantially accelerated by inflammatory factors within ALL BM. CD34 ${ }^{+}$cells were purified from UCB and stimulated with control or inflammatory supernatants collected from normal or ALL BM, followed by a 3-weekstromal cell coculture. Newly produced cells were further identified and enumerated by multiparametric flow cytometry (a). The indicated gates were used to determine cell frequencies within the culture for $\mathrm{CD} 34^{+}$cells, $\mathrm{CD} 34^{+} \mathrm{CD} 56^{+}$differentiating NK precursor cells, and CD56 ${ }^{+}$ NK cells (shown in (a) upper panel). Further fractionation of the $\mathrm{CD}^{-} 4^{-} \mathrm{CD} 56^{-}$compartment allows the identification of CD11c ${ }^{+} \mathrm{DC}$ and

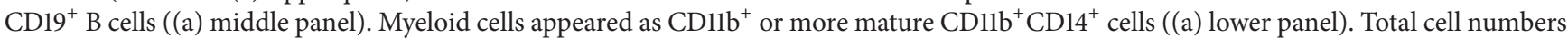
from each treatment condition were calculated and expressed as yields per input progenitor (b). Control SN or C: control supernatant; Infl SN or I: inflammatory supernatant. Data are representative of three independent experiments. Supernatant from different individuals was used for each experiment. 
is part of a network of proinflammatory molecules including CXCL12 and CCL2 chemokines, IL-6, macrophage inhibitory factor (MIF), and vascular endothelial growth factor (VEGF), among others [11]. For hematological neoplasias, there are experimental observations indicating the use of autocrine TNF $\alpha$ by leukemic initiating cells for their survival and proliferation, in a $\mathrm{NF} \kappa \mathrm{B}$-dependent manner [53]. On the other hand, the participation of IL- $1 \beta$ in the pathogenesis of acute myeloid leukemia has been documented, indicating that its signals in leukemic stem cells disrupt the dormant state and induce its proliferation potential [54]. Moreover, regulation of the NLRP3 inflammasome may explain the activity of IL1 $\beta$ in promyelocytic leukemia, as described in other models $[55,56]$. The contribution of a particular inflammasome in the activation of inflammatory processes in B-ALL remains to be determined, as well as the putative activator of the oligomer inside the ALL cells.

To our knowledge, this is the first investigation on the influence of an inflammatory microenvironment in early hematopoietic development during lymphoid leukemia settings. The findings suggest that an ALL subset expressing myeloid antigens is associated with in vitro secretion of a number of cytokines, predominantly Th1-type, which, in turn, regulate proliferation and differentiation of primitive normal cells. Our data entails the NF $\kappa$ B and STAT3 signaling in ALL cells with the creation of abnormal hematopoietic niches that may disrupt effective long-term blood cell formation processes. The mechanisms involved may include induction of growth factor receptors [37]. Of special interest will be the implication of specific genetic aberrations in the triggering of ALL-inflammation setting. Although a role for $\mathrm{NF} \kappa \mathrm{B}$ in leukemogenesis is possible, the etiology and maintenance of ALL remain unknown in most cases [57]. The included patients in this study were not clinically identified as infected, arguing in favor of a "sterile" local inflammation. Besides, a conspicuous population of individuals behaved as "noninflammatory," suggesting that the abnormal environment appears as a consequence of the activity of leukemic cells.

\section{Concluding Remarks}

There are great expectations for the biomedical research to unravel fundamental aspects of ALL pathogenesis from the earliest events of normal and neoplastic differentiation within bone marrow. Although the stability of the hematopoietic system has long been recognized, it has become clear that plasticity of stem and progenitor cells allows the crucial regulation of primitive cell compartments during inflammation. Furthermore, recent studies have highlighted the importance of chronic inflammation in development and maintenance of some malignancies. Our findings suggest the manipulation of the environment by a special type of leukemic cells that might disrupt the normal HSC-niche communication at the time tumor progression is promoted. The relevance of a rigorous multiparametric flow cytometry phenotyping and purification of the suggested leukemic cell populations producing proinflammatory cytokines is high for current and future investigations.
Decoding its possible relationship to the biology and prognosis of childhood acute leukemias is crucial for the design of therapeutic strategies based on manipulation of the tumor microenvironment.

\section{Conflict of Interests}

The authors declare that they have no conflict of interests.

\section{Acknowledgments}

This work was supported by the "Federico Gómez" Children's Hospital (Grant HIM/018/2013) and by the National Council of Science and Technology (CONACyT) (Grant CB-201001-152695). Adriana Contreras-Quiroz and Eduardo Vadillo acknowledge the scholarship provided by CONACyT. This work constitutes a partial fulfillment of the Graduate Program of Master's Degree in Clinical Biochemistry of the National Autonomous University of Mexico, UNAM (AVO). The authors are grateful to Drs. Guadalupe Alarcón and Leticia Alemán-Lazarini for their professional assistance in providing cord blood specimens and in confocal microscopy, respectively. Briceida López-Martínez and Rosana Pelayo contribute equally to this work.

\section{References}

[1] F. R. Balkwill and A. Mantovani, "Cancer-related inflammation: common themes and therapeutic opportunities," Seminars in Cancer Biology, vol. 22, no. 1, pp. 33-40, 2012.

[2] B. E. Lippitz, "Cytokine patterns in patients with cancer: a systematic review," The Lancet Oncology, vol. 14, no. 6, pp. e218e228, 2013.

[3] Y. Ben-Neriah and M. Karin, "Inflammation meets cancer, with NF- $\kappa \mathrm{B}$ as the matchmaker," Nature Immunology, vol. 12 , no. 8 , pp. 715-723, 2011.

[4] A. Mantovani, P. Allavena, A. Sica, and F. Balkwill, "Cancerrelated inflammation," Nature, vol. 454, no. 7203, pp. 436-444, 2008.

[5] P. Andreu, M. Johansson, N. I. Affara et al., "FcR $\gamma$ activation regulates inflammation-associated squamous carcinogenesis," Cancer Cell, vol. 17, no. 2, pp. 121-134, 2010.

[6] D. I. Gabrilovich, S. Ostrand-Rosenberg, and V. Bronte, "Coordinated regulation of myeloid cells by tumours," Nature Reviews Immunology, vol. 12, no. 4, pp. 253-268, 2012.

[7] N. Erez, M. Truitt, P. Olson, and D. Hanahan, "Cancer-associated fibroblasts are activated in incipient neoplasia to orchestrate tumor-promoting inflammation in an NF- kappaB dependent manner," Cancer Cell, vol. 17, no. 2, pp. 135-147, 2010.

[8] W. E. Naugler and M. Karin, "The wolf in sheep's clothing: the role of interleukin-6 in immunity, inflammation and cancer," Trends in Molecular Medicine, vol. 14, no. 3, pp. 109-119, 2008.

[9] A. Mantovani, B. Savino, M. Locati, L. Zammataro, P. Allavena, and R. Bonecchi, "The chemokine system in cancer biology and therapy," Cytokine \& Growth Factor Reviews, vol. 21, no. 1, pp. $27-39,2010$.

[10] M. Karin, "Nuclear factor- $\kappa \mathrm{B}$ in cancer development and progression," Nature, vol. 441, no. 7092, pp. 431-436, 2006. 
[11] H. Kulbe, R. Thompson, J. L. Wilson et al., "The inflammatory cytokine tumor necrosis factor- $\alpha$ generates an autocrine tumorpromoting network in epithelial ovarian cancer cells," Cancer Research, vol. 67, no. 2, pp. 585-592, 2007.

[12] J. Purizaca, I. Meza, and R. Pelayo, "Early lymphoid development and microenvironmental cues in B-cell acute lymphoblastic leukemia," Archives of Medical Research, vol. 43, no. 2, pp. 89-101, 2012.

[13] E. Dorantes-Acosta, E. Vadillo, A. Contreras-Quiroz et al., "TLR stimulation of bone marrow lymphoid precursors from childhood acute leukemia modifies their differentiation potentials," BioMed Research International, vol. 2013, Article ID 846724, 13 pages, 2013.

[14] R. Pelayo, E. Vadillo, and E. Dorantes, "From HSC to B-lymphoid cells in normal and malignant hematopoiesis," in Advances in Hematopoietic Stem Cell Research, InTech, 2013.

[15] J. Purizaca, A. Contreras-Quiroz, E. Dorantes-Acosta et al., "Lymphoid progenitor cells from childhood acute lymphoblastic leukemia are functionally deficient and express high levels of the transcriptional repressor Gfi-1," Clinical and Developmental Immunology, vol. 2013, Article ID 349067, 12 pages, 2013.

[16] C. V. Cox, P. Diamanti, R. S. Evely, P. R. Kearns, and A. Blair, "Expression of CD133 on leukemia-initiating cells in childhood ALL," Blood, vol. 113, no. 14, pp. 3287-3296, 2009.

[17] E. Dorantes-Acosta and R. Pelayo, "Lineage switching in acute leukemias: a consequence of stem cell plasticity?" Bone Marrow Research, vol. 2012, Article ID 406796, 18 pages, 2012.

[18] M. Greaves, "Infection, immune responses and the aetiology of childhood leukaemia," Nature Reviews Cancer, vol. 6, no. 3, pp. 193-203, 2006.

[19] A. M. Ford, C. Palmi, C. Bueno et al., "The TEL-AML1 leukemia fusion gene dysregulates the TGF- $\beta$ pathway in early B lineage progenitor cells," The Journal of Clinical Investigation, vol. 119, no. 4, pp. 826-836, 2009.

[20] H.-P. Kantner, W. Warsch, A. Delogu et al., "ETV6/RUNX1 induces reactive oxygen species and drives the accumulation of DNA damage in B cells," Neoplasia, vol. 15, no. 11, pp. 1292-1300, 2013.

[21] E. Papaemmanuiel, I. Rapado, Y. Li et al., "RAG-mediated recombination is the predominant driver of oncogenic rearragement in ETV6-RUNX1 acute lymphoblastic leukemia," Nature Genetics, vol. 46, no. 2, pp. 116-125, 2014.

[22] A. Colmone, M. Amorim, A. L. Pontier, S. Wang, E. Jablonski, and D. A. Sipkins, "Leukemic cells create bone marrow niches that disrupt the behavior of normal hematopoietic progenitor cells," Science, vol. 322, no. 5909, pp. 1861-1865, 2008.

[23] M. H. G. P. Raaijmakers, "Niche contributions to oncogenesis: emerging concepts and implications for the hematopoietic system," Haematologica, vol. 96, no. 7, pp. 1041-1048, 2011.

[24] S. Khalid, B. Moiz, S. N. Adil, and M. Khurshid, "Retrospective review of pediatric patients with acute lymphoblastic leukemia: a single center experience," Indian Journal of Pathology and Microbiology, vol. 53, no. 4, pp. 704-710, 2010.

[25] L. Espinoza-Hernández, J. Cruz-Rico, H. Benítez-Aranda et al., "In vitro characterization of the hematopoietic system in pediatric patients with acute lymphoblastic leukemia," Leukemia Research, vol. 25, no. 4, pp. 295-303, 2001.

[26] J. G. Juarez, M. Thien, A. D. Pena, R. Baraz, K. F. Bradstock, and L. J. Bendall, "CXCR4 mediates the homing of B cell progenitor acute lymphoblastic leukaemia cells to the bone marrow via activation of p38MAPK," British Journal of Haematology, vol. 145, no. 4, pp. 491-499, 2009.
[27] M. L. Guzman, R. M. Rossi, L. Karnischky et al., "The sesquiterpene lactone parthenolide induces apoptosis of human acute myelogenous leukemia stem and progenitor cells," Blood, vol. 105, no. 11, pp. 4163-4169, 2005.

[28] M. L. Guzman, S. J. Neering, D. Upchurch et al., "Nuclear factor$\kappa \mathrm{B}$ is constitutively activated in primitive human acute myelogenous leukemia cells," Blood, vol. 98, no. 8, pp. 2301-2307, 2001.

[29] T. Nagasawa, Y. Omatsu, and T. Sugiyama, "Control of hematopoietic stem cells by the bone marrow stromal niche: the role of reticular cells," Trends in Immunology, vol. 32, no. 7, pp. 315320, 2011.

[30] R. S. Welner, R. Pelayo, Y. Nagai et al., "Lymphoid precursors are directed to produce dendritic cells as a result of TLR9 ligation during herpes infection," Blood, vol. 112, no. 9, pp. 3753-3761, 2008.

[31] D. Cain, M. Kondo, H. Chen, and G. Kelsoe, "Effects of acute and chronic inflammation on B-cell development and differentiation," Journal of Investigative Dermatology, vol. 129, no. 2, pp. 266-277, 2009.

[32] M. T. Baldridge, K. Y. King, N. C. Boles, D. C. Weksberg, and M. A. Goodell, "Quiescent haematopoietic stem cells are activated by IFN- $\gamma$ in response to chronic infection," Nature, vol. 465, no. 7299, pp. 793-797, 2010.

[33] H. Takizawa, S. Boettcher, and M. G. Manz, "Demand-adapted regulation of early hematopoiesis in infection and inflammation," Blood, vol. 119, no. 13, pp. 2991-3002, 2012.

[34] M. T. Baldridge, K. Y. King, and M. A. Goodell, "Inflammatory signals regulate hematopoietic stem cells," Trends in Immunology, vol. 32, no. 2, pp. 57-65, 2011.

[35] J. R. Boiko and L. Borghesi, "Hematopoiesis sculpted by pathogens: Toll-like receptors and inflammatory mediators directly activate stem cells," Cytokine, vol. 57, no. 1, pp. 1-8, 2012.

[36] E. Vadillo, E. Dorantes-Acosta, and R. Pelayo, "Regulation of hematopoietic stem/progenitor cell development by inflammation cues," in Molecular Aspects of Inflammation, L. PérezMartínez, G. Pedraza-Alva, and E. F. Osorio, Eds., Res Signpost 37/661 (2), pp. 71-87, 2014.

[37] E. Vadillo, E. Dorantes-Acosta, and L. Arriaga-Pizano, "Adult, but not neonatal, human lymphoid progenitors respond to TLR9 ligation by producing functional NK-like cells," Experimental Hematology, vol. 42, no. 7, pp. 562-573, 2014.

[38] A. G. Zaretsky, J. B. Engiles, and C. A. Hunter, "Infectioninduced changes in hematopoiesis," The Journal of Immunology, vol. 192, no. 1, pp. 27-33, 2014.

[39] M. Sioud, Y. Fløisand, L. Forfang, and F. Lund-Johansen, "Signaling through toll-like receptor $7 / 8$ induces the differentiation of human bone marrow CD34+ progenitor cells along the myeloid lineage," Journal of Molecular Biology, vol. 364, no. 5, pp. 945-954, 2006.

[40] M. Sioud and Y. Fløisand, "TLR agonists induce the differentiation of human bone marrow $\mathrm{CD}_{3} 4^{+}$progenitors into CD11c ${ }^{+}$CD80/86 ${ }^{+}$DC capable of inducing a Th1-type response," European Journal of Immunology, vol. 37, no. 10, pp. 2834-2846, 2007.

[41] S. A. Lee, S. M. Kim, Y. H. Son et al., "Peptidoglycan enhances secretion of monocyte chemoattractants via multiple signaling pathways," Biochemical and Biophysical Research Communications, vol. 408, no. 1, pp. 132-138, 2011.

[42] R. S. Welner and P. W. Kincade, "9-1-1: HSCs respond to emergency calls," Cell Stem Cell, vol. 14, no. 4, pp. 415-416, 2014. 
[43] J. L. Zhao, C. Ma, R. M. O'Connell et al., "Conversion of danger signals into cytokine signals by hematopoietic stem and progenitor cells for regulation of stress-induced hematopoiesis," Cell Stem Cell, vol. 14, no. 4, pp. 445-459, 2014.

[44] U. Schulz, R. Munker, B. Ertl, E. Holler, and H. J. Kolb, “Different types of human leukemias express the message for TNF-alpha and interleukin-10," European Journal of Medical Research, vol. 6, no. 8, pp. 359-363, 2001.

[45] C. Kebelmann-Betzing, G. Körner, L. Badiali et al., "Characterization of cytokine, growth factor receptor, costimulatory and adhesion molecule expression patterns of bone marrow blasts in relapsed childhood B cell precursor all," Cytokine, vol. 13, no. 1, pp. 39-50, 2001.

[46] S. Wu, R. Geßner, A. Von Stackelberg, R. Kirchner, G. Henze, and K. Seeger, "Cytokine/cytokine receptor gene expression in childhood acute lymphoblastic leukemia: correlation of expression and clinical outcome at first disease recurrence," Cancer, vol. 103, no. 5, pp. 1054-1063, 2005.

[47] C. Cocco and I. Airoldi, "Cytokines and microRNA in pediatric B-acute lymphoblastic leukemia," Cytokine and Growth Factor Reviews, vol. 22, no. 3, pp. 149-156, 2011.

[48] C. M. Schürch, C. Riether, and A. F. Ochsenbein, "Cytotoxic $\mathrm{CD}^{+} \mathrm{T}$ cells stimulate hematopoietic progenitors by promoting cytokine release from bone marrow mesenchymal stromal cells," Cell Stem Cell, vol. 14, no. 4, pp. 460-472, 2014.

[49] S. I. Grivennikov and M. Karin, "Dangerous liaisons: STAT3 and NF- $\kappa$ B collaboration and crosstalk in cancer," Cytokine and Growth Factor Reviews, vol. 21, no. 1, pp. 11-19, 2010.

[50] M. Mangolini, J. de Boer, V. Walf-Vorderwülbecke, R. Pieters, M. L. den Boer, and O. Williams, "STAT3 mediates oncogenic addiction to TEL-AML1 in $\mathrm{t}(12 ; 21)$ acute lymphoblastic leukemia.," Blood, vol. 122, no. 4, pp. 542-549, 2013.

[51] H. Zhang, H. Nguyen-Jackson, A. D. Panopoulos, H. S. Li, P. J. Murray, and S. S. Watowich, "STAT3 controls myeloid progenitor growth during emergency granulopoiesis," Blood, vol. 116, no. 14, pp. 2462-2471, 2010.

[52] A. Trumpp, M. Essers, and A. Wilson, "Awakening dormant haematopoietic stem cells," Nature Reviews Immunology, vol. 10, no. 3, pp. 201-209, 2010.

[53] P. Gallipoli, F. Pellicano, H. Morrison et al., "Autocrine TNF- $\alpha$ production supports CML stem and progenitor cell survival and enhances their proliferation," Blood, vol. 122, no. 19, pp. 33353339, 2013.

[54] J. Yang, T. Ikezoe, C. Nishioka, A. Nobumoto, and A. Yokoyama, "IL-1 $\beta$ inhibits self-renewal capacity of dormant CD $34^{+} / \mathrm{CD} 38^{-}$ acute myelogenous leukemia cells in vitro and in vivo," vol. 133, no. 8, pp. 1967-1981, 2013.

[55] L. Zitvogel, O. Kepp, L. Galluzzi, and G. Kroemer, "Inflammasomes in carcinogenesis and anticancer immune responses," Nature Immunology, vol. 13, no. 4, pp. 343-351, 2012.

[56] M. Okamoto, W. Liu, Y. Luo et al., "Constitutively active inflammasome in human melanoma cells mediating autoinflammation via caspase-1 processing and secretion of interleukin-1 $\beta$," The Journal of Biological Chemistry, vol. 285, no. 9, pp. 64776488, 2010.

[57] J. Krawczyk, M. O’Dwyer, R. Swords et al., "The role of inflammation in leukemia," in Inflammation and Cancer, vol. 816 of Advances in Experimental Medicine and Biology, pp. 335-360, Springer, Basel, Switzerland, 2014. 


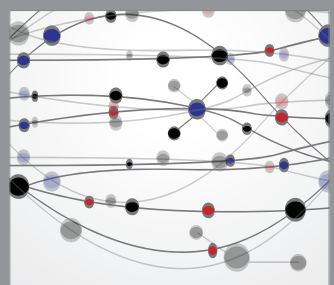

The Scientific World Journal
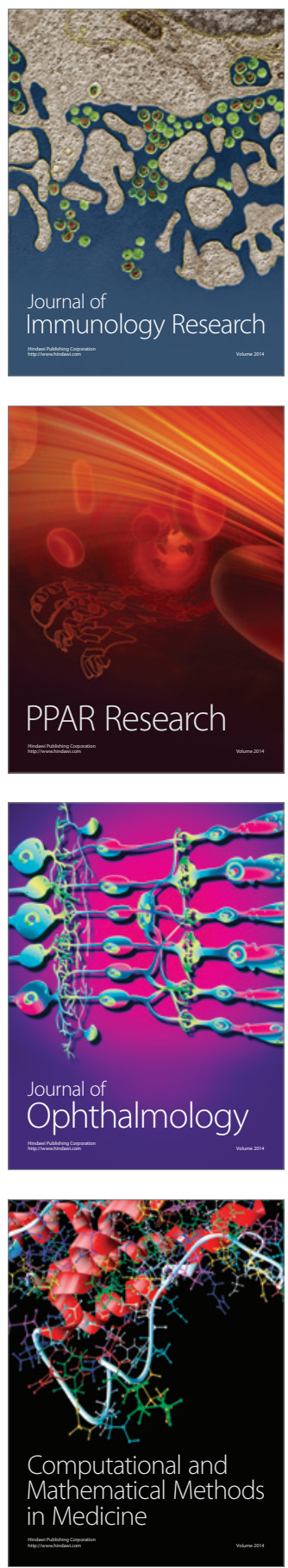

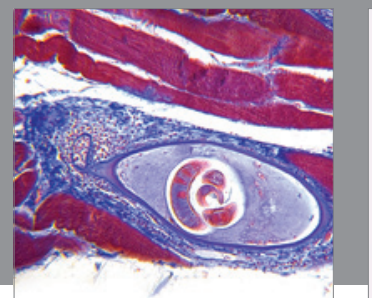

Gastroenterology

Research and Practice
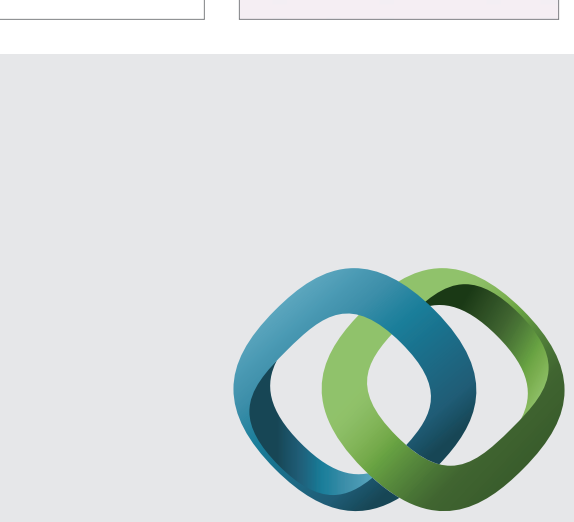

\section{Hindawi}

Submit your manuscripts at

http://www.hindawi.com
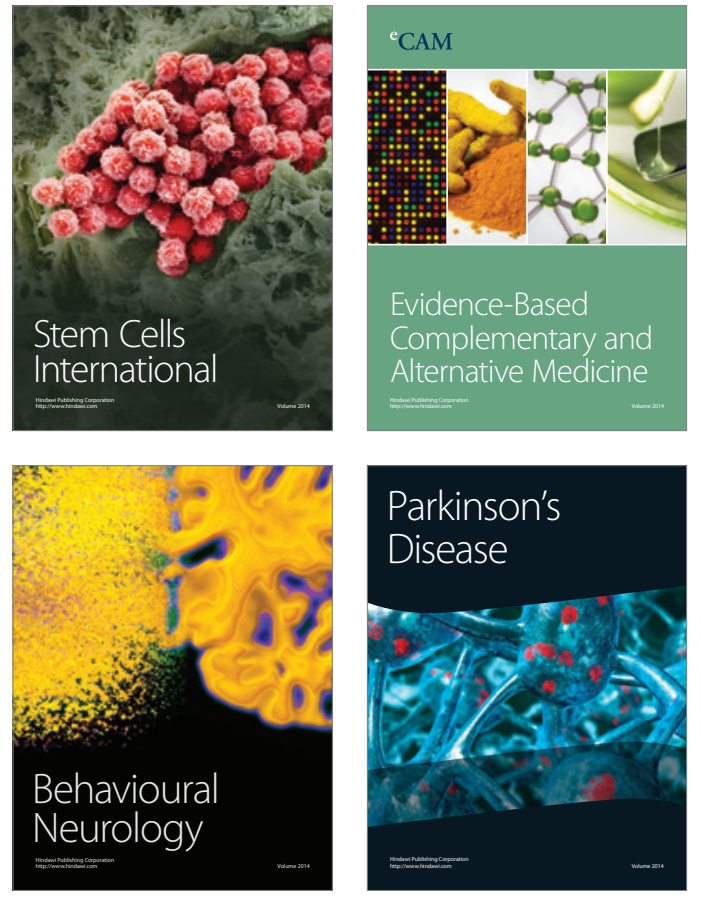
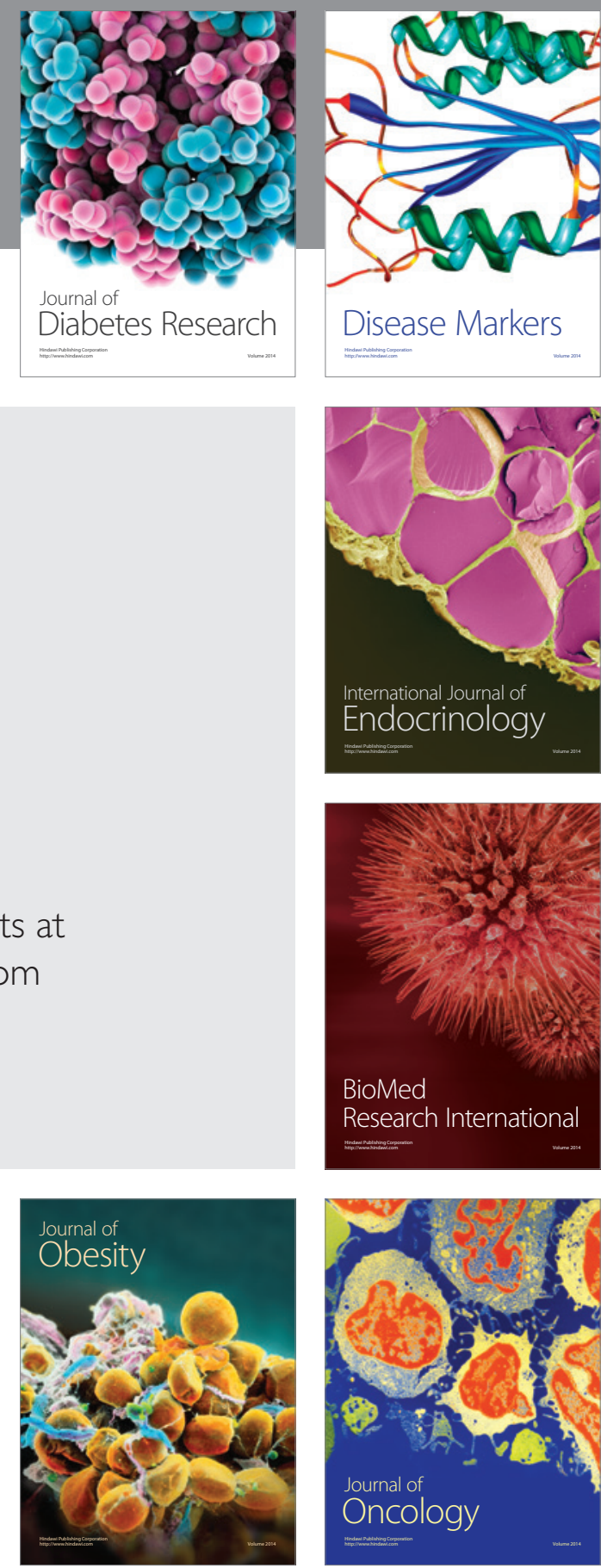

Disease Markers
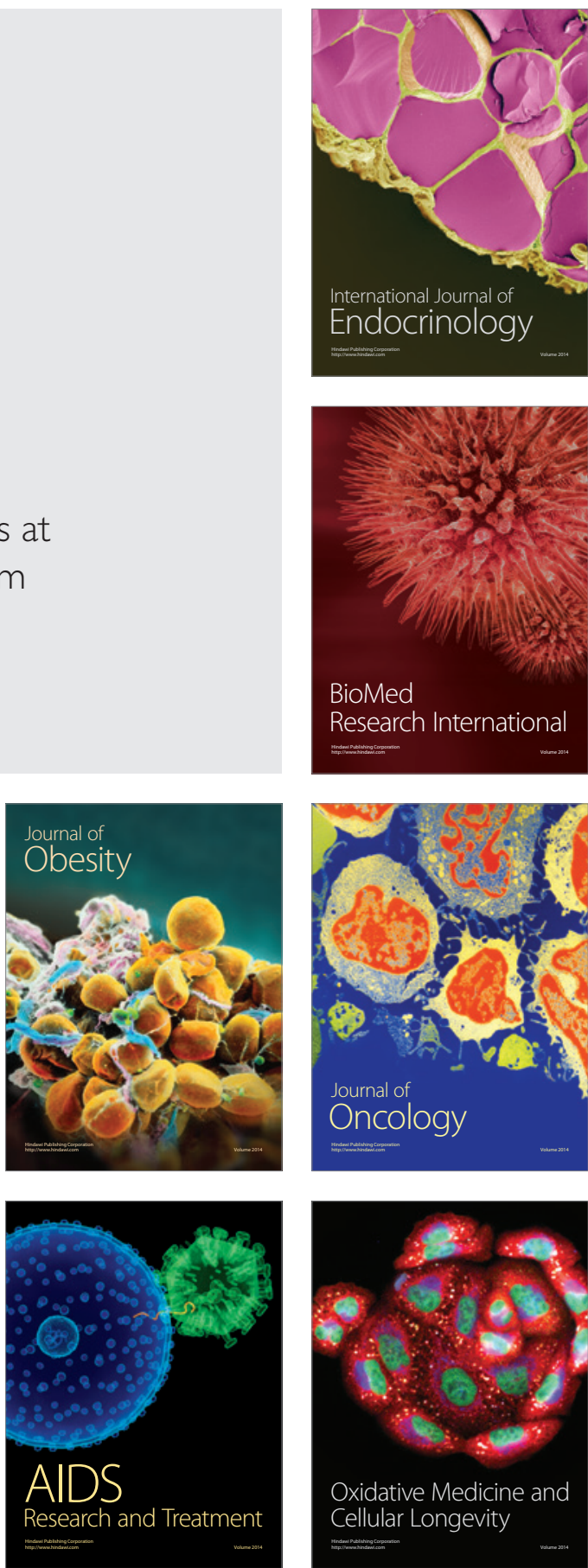